\title{
Determinants of Competitive Antagonist Sensitivity on Neuronal Nicotinic Receptor $\beta$ Subunits
}

\author{
Scott C. Harvey and Charles W. Luetje \\ Department of Molecular and Cellular Pharmacology, University of Miami School of Medicine, Miami, Florida 33101
}

We constructed a series of chimeric and mutant neuronal nic otinic acetylcholine receptor $\beta$ subunits to map amino acid residues that determine sensitivity to competitive antagonists. The $\beta 2$ and $\beta 4$ subunits form pharmacologically distinct receptors when expressed in combination with the $\alpha 3$ subunit in Xenopus oocytes. At equipotent acetylcholine concentrations, $\alpha 3 \beta 2$ is 56 -fold more sensitive to blockade by dihydro- $\beta$ erythroidine than is $\alpha 3 \beta 4$. The $\alpha 3 \beta 2$ combination is also sensitive to long-term blockade by neuronal bungarotoxin, whereas $\alpha 3 \beta 4$ is not. Pharmacological analysis of receptors formed by chimeric $\beta$ subunits reveals that amino acid residues that determine both dihydro- $\beta$-erythroidine and neuronal bungarotoxin sensitivity are located within several sequence segments. The major determinant of sensitivity to both competitive antagonists is located between residues 54 and 63. A minor determinant of sensitivity to both antagonists lies between residues 1 and 54, whereas a minor determinant of NBT sensitivity lies between residues 74 and 80 . Within region 54-63 of $\beta 2$, mutant $\beta 2$ subunits were used to identify threonine 59 as a residue critical in determining competitive antagonist sensitivity. Changing threonine 59 to lysine, as occurs in $\beta 4$, causes a 9 -fold decrease in dihydro- $\beta$-erythroidine sensitivity and a 71 fold decrease in neuronal bungarotoxin sensitivity. Changing polar threonine 59 to negatively charged aspartate causes a 2.5-fold increase in neuronal bungarotoxin sensitivity and has no effect on dihydro- $\beta$-erythroidine sensitivity.

Key words: nicotinic receptor; neuronal; antagonists; mutant; chimera; neuronal bungarotoxin; dihydro- $\beta$-erythroidine
Nicotinic acetylcholine receptors (nAChRs) are found throughout the central and peripheral nervous systems, with 11 distinct genes encoding neuronal $\mathrm{nAChR}$ subunits $(\alpha 2-\alpha 9, \beta 2-\beta 4)$ currently identified (Sargent, 1993; Elgoyhen et al., 1994). Functional neuronal nAChRs can be formed in Xenopus oocytes by expression of various combinations of these subunits (Duvoisin et al., 1989; Papke et al., 1989; Luetje et al., 1990b; Luetje and Patrick, 1991). Although these neuronal $\mathrm{nAChR}$ subunits are homologous with one another, each functional subunit combination is pharmacologically distinct. This may account for the diversity of neuronal nAChRs observed in vivo (Luetje et al., 1990a; Role, 1992; Sargent, 1993).

Identification of amino acid residues that are involved in forming the ligand-binding sites of $\mathbf{n A C h R s}$ is essential to understanding how these receptors function. Affinity labeling experiments have identified several critical amino acid residues of the muscletype $\alpha$ subunit (Kao et al., 1984; Dennis et al., 1988; Abramson et al., 1989; Galzi et al., 1990; Middleton and Cohen, 1991). Non- $\alpha$ subunits are also involved in forming the ligand-binding site. The ligand-binding sites of muscle nAChRs appear to be located at the interface between the $\alpha$ and $\gamma$ subunits and between the $\alpha$ and $\delta$ subunits (Blount and Merlie, 1989; Pederson and Cohen, 1990; Czajkowski and Karlin, 1991; Middleton and Cohen, 1991). The ligand-binding sites of neuronal nAChRs appear to be formed in

Received Nov. 6, 1995; revised Feb. 15, 1996; accepted April 2, 1996.

This work was supported by grants to C.W.L. from the National Institute on Drug Ahuse (DA08102), the American Heart Association Florida Affiliate, and the Pharmaceutical Research and Manufacturers of America Foundation. C.W.L. is an Initial Investigator of the American Heart Association. Florida Affiliate. We thank Floyd Maddox for tcchnical assistance.

Correspondence should be addressed to Dr. Charles W. Luctje, Department of Molecular and Cellular Pharmacology (R-189), University of Miami School of Medicine, P.O. Box 016189, Miamı, FL 33101.

Copyright 1996 Socicty for Neuroscience $0270-6474 / 96 / 163798-(09 \$ 05.00 / 0$ a similar manner, because both $\alpha$ and $\beta$ subunits influence the pharmacological properties of these receptors (Luetje and Patrick, 1991). The residues identified by affinity labeling experiments, using Torpedo electric organ nAChRs, are highly conserved among muscle and neuronal nAChR subunits. Thus, these residues may form parts of the ligand-binding site common to all $\mathrm{nAChRs}$, but cannot be responsible for the pharmacological diversity observed among $\mathrm{nAChR}$ subtypes.

An approach to identification of the amino acid residues of receptor subunits that confer differential pharmacological properties is to construct chimeras of pharmacologically distinct subunits. This approach has been used to identify several sequence segments of neuronal $\mathrm{nAChR} \alpha$ subunits that affect sensitivity to agonists and the competitive antagonist neuronal bungaroluxin (NBT) (Luetje et al., 1993). Chimeric subunits have been used to identify regions of $\beta 2$ and $\beta 4$ that determine sensitivity to agonists (Figl et al., 1992; Cohen et al., 1995). This technique has also been used to localize the $\beta$ subunit contribution to NBT sensitivity to the N-terminal 119 (Papke et al., 1993) or 80 (Wheeler et al., 1993) residues of $\beta 2$.

We constructed a series of chimeric $\beta$ subunits to more precisely identify regions of $\beta$ subunits that determine competitive antagonist sensitivity. We used the structurally distinct competitive antagonists dihydro- $\beta$-erythroidine $(\mathrm{DH} \beta \mathrm{E})$ and NBT, which can distinguish between the $\alpha 3 \beta 2$ and $\alpha 3 \beta 4$ subunit combinations. Having identified residues 54-63 of $\beta 2$ as containing the major determinant of competitive antagonist sensitivity, we then used a series of mutant $\beta$ subunits to identify threonine 59 as the critical residue within this region.

\section{MATERIALS AND METHODS}

Materials. Xenopus laevis frogs were purchased from Nasco. RNA transcription kits were from Ambion. ACh, atropine, and 3-aminobenzoic acid ethyl ester were from Sigma (St. Louis, MO). Collagenase B was 
from Boehringer Mannheim (Indianapolis, IN). Sequenase 2.0 kits were from United States Biochemicals (Cleveland, OH). NBT was from Biotoxins. CloneAmp kits were from Gibco (Gaithersburg, MD). DH $\beta E$ was a gift from Merck (Rahway, NJ).

Mutagenesis and construction of chimeric receptors. Chimeric and $\mathrm{mu-}$ tant subunits were constructed using PCR (Higuchi, 1990). Our notation for these subunits is to list the source of the $\mathrm{N}$ terminal portion, followed by the residue number in the amino acid sequence in which the chimeric joint is made (numbering taken from the mature $\beta 2$ subunit sequence), followed by the source of the C-terminal portion. For example, the chimeric subunit $\beta 4-204-\beta 2$ is composed of $\beta 4$ sequence from the $N$ terminus until residue 204 , after which it is composed of $\beta 2$ sequence. The $\beta 2$ and $\beta 4$ cDNAs in the Bluescript $\mathrm{SK}^{-}$vector were used as templates for PCR reactions. PCR products were subcloned into the pAMP1 vector using a CloneAmp kit (Gibco) or into the pCR-Script SK ${ }^{+}$ vector (Stratagene, La Jolla, CA). To minimize the amount of PCR product in the final construct that would have to be sequenced, as much PCR product as possible was replaced with wild-type $\beta 2$ or $\beta 4$ sequence using existing restriction sites. Remaining sequence derived from PCR product was sequenced using Sequenase 2.0 (United States Biochemicals).

Injection of in vitro synthesized $R N A$ into Xenopus oocytes. $\mathrm{m}^{7} \mathrm{G}\left(5^{\prime}\right) \mathrm{ppp}\left(5^{\prime}\right) \mathrm{G}$-capped cRNA was synthesized in vitro from linearized template DNA encoding the $\alpha 3, \beta 2$, and $\beta 4$ subunits, as well as the various chimeric and mutant subunits, using an Ambion mMessage mMachine kit. Mature $X$. laevis frogs were anesthetized by submersion in $0.1 \%$ 3 -aminobenzoic acid cthyl ester, and oocytes were surgically removed. Follicle cells were removed by treatment with collagenase B for 2 hr at room temperature. Each oocyte was injected with 5-50 ng of cRNA in 50 nl of water and incubated at $19^{\circ} \mathrm{C}$ in modified Barth's saline $(88 \mathrm{~mm} \mathrm{NaCl}$, $1 \mathrm{mM} \mathrm{KCl}, 2.4 \mathrm{~mm} \mathrm{NaHCO}, 0.3 \mathrm{mM} \mathrm{CaNO}_{3}, 0.41 \mathrm{mM} \mathrm{CaCl}_{2}, 0.82 \mathrm{~mm}$ $\mathrm{MgSO}_{4}, 100 \mu \mathrm{g} / \mathrm{ml}$ gentamicin, and $15 \mathrm{~mm}$ IIEPES, pI I 7.6) for 2-7 d. RNA transcripts encoding each subunit were injected into oocytes at a molar ratio of $1: 1$.

Electrophysiological recordings. Oocytes were perfused at room temperature $\left(20-25^{\circ} \mathrm{C}\right)$, in a $300 \mu \mathrm{l}$ chamber with perfusion solution $(115 \mathrm{~mm}$ $\mathrm{NaCl}, 1.8 \mathrm{mM} \mathrm{CaCl}_{2}, 2.5 \mathrm{~mm} \mathrm{KCl}, 10 \mathrm{mM}$ HEPES, $\mathrm{pH} 7.2$, and $1.0 \mu \mathrm{M}$ atropine). Perfusion was continuous at a rate of $\sim 20 \mathrm{ml} / \mathrm{min}$. ACh was diluted in perfusion solution, and the oocytes were exposed to $\mathrm{ACh}$ for $\sim 10$ sec using a solenoid valve. NBT sensitivity was tested by comparing ACh-induced current responses before and after the oocytes were incubated for $30 \mathrm{~min}$ in perfusion solution containing various concentrations of NBT and $100 \mu \mathrm{g} / \mathrm{ml}$ bovine serum albumin. Preincubation with NBT results in a slowly reversible competitive blockade of $\alpha 3 \beta 2$ but not $\alpha 3 \beta 4$ (Boulter et al., 1987; Duvoisin et al., 1989; Luetje et al., 1990b). DH $\beta E$ sensitivity was tested by measuring the reduction of ACh-induced current responses when $\mathrm{DH} \beta \mathrm{E}$ was coapplied with $\mathrm{ACh}$. The response to $\mathrm{ACh}$ alone, before treatment with either NBT or DH $\beta E$, is taken as the control response. The ACh-induced response, after treatment with NBT or during coapplication with $\mathrm{DH} \beta \mathrm{E}$, is reported as a percent of the control response.

Current responses to agonist application were measured under twoelectrode voltage clamp, at a holding potential of $-70 \mathrm{mV}$, using a Knight Industrial Technologies voltage clamp unit. Micropipettes were filled with $3 \mathrm{M} \mathrm{KCl}$ and had resistances of $0.5-1.0 \mathrm{M} \Omega$. Agonist-induced responses were captured, stored, and analyzed on a Macintosh IIci conputer using a data acquisition program written with LabVIEW (National Instruments) and LIBI (University of Arizona) software (Luetje et al., 1993).

Dose-response and dose-inhibition data were fit with Passage II software by the nonlinear lcast-squares mcthod. For dose-response data, we used the equation: current $=$ maximum current $/\left[1+\left(\mathrm{EC}_{50} /[\text { agonist }]\right)^{n}\right]$, where $n$ and $\mathrm{EC}_{50}$ represent the Hill coefficient and the agonist concentration producing half-maximal response, respectively. Rapid desensitization of these receptors can affect the accuracy of dose-response curves. However, this was found to account for only a small fraction of the difference in $\mathrm{EC}_{50}$ between $\alpha 3 \beta 2$ and $\alpha 3 \beta 4$ (Cohen ct al., 1995). Rapid desensitization also makes the maximal response an unrcliable standard with which to normalize data. For this reason, we normalized each response to the response to a low concentration of agonist. To compare and display results for different receptors, we then renormalized each value to the fit maximal response. For $\mathrm{DH} \beta \mathrm{E}$ dose-inhibition data, we used the equation: current $=$ maximum current $/[1+$ ([antagonist $] /$ $\left.\left.\mathrm{IC}_{50}\right)^{n}\right]$, where $n$ and $\mathrm{IC}_{50}$ represent the Hill coefficient and the antagonist concentration producing half-maximal inhibition, respectively. Fold dif-
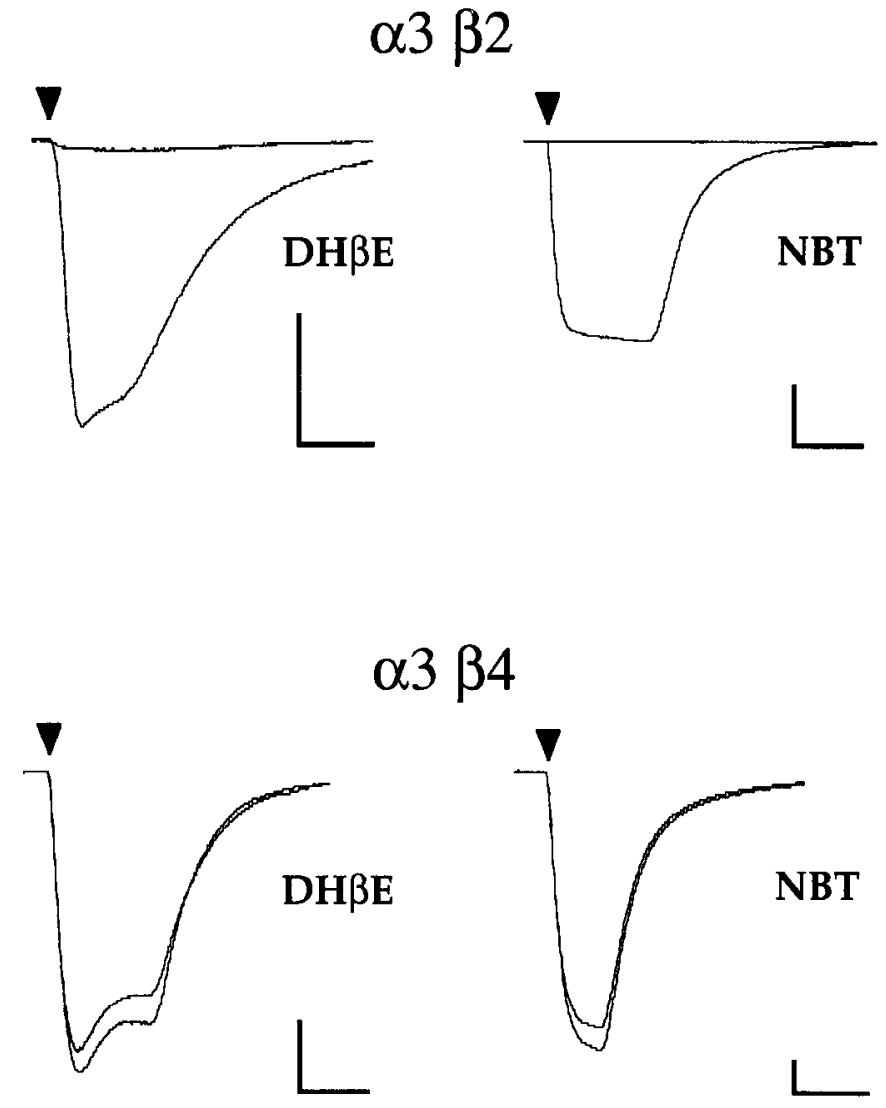

Figure 1. $\alpha 3 \beta 2$ and $\alpha 3 \beta 4$ are pharmacologically distinct. Top traces, Current responses of an $\alpha 3 \beta 2$-cxpressing oocyte to $10 \mu \mathrm{M} \mathrm{ACh}$ alone and in combination with $3 \mu \mathrm{M} \mathrm{DH \beta E}$ (left), and current responses of a different $\alpha 3 \beta 2$-expressing oocyte to $1 \mu \mathrm{M} \mathrm{ACh}$ before and after $30 \mathrm{~min}$ incubation with $100 \mathrm{nM} \mathrm{NBT}$ (right). Bottom traces, Current responses of an $\alpha 3 \beta 4$ expressing oocyte to $100 \mu \mathrm{M} \mathrm{ACh}$ alone or in combination with $3 \mu \mathrm{M}$ $D H \beta E$ (left), and current responses of a different $\alpha 3 \beta 4$-expressing oocyte to $10 \mu \mathrm{M}$ ACh before and after 30 min incubation with $100 \mathrm{nM} \mathrm{NBT}$ (right) ACh application of $\sim 10 \mathrm{sec}$ is indicated by arrowheads. Scale bars: $150 \mathrm{nA}$, $10 \mathrm{sec}$.

ferences between NBT dose-inhibition data for various receptors were determined by visual inspection of Figure $5 B$. Statistical significance was determined by using a two-sample $t$ test after an F test to ensure equality of variance. For samples with unequal variance $(p>0.05)$, statistical significance was determined by using a two-sample $t$ test for samples with unequal variance (Cochran's method).

\section{RESULTS}

The $\beta 2$ and $\beta 4$ subunits form receptors that are differentially sensitive to competitive antagonists

The $\beta 2$ and $\beta 4$ subunits each can form functional neuronal nAChRs when expressed in Xenopus oocytes in combination with $\alpha 3$ (Fig. 1). These two subunit combinations differ in their sensitivity to both $\mathrm{DH} \beta \mathrm{E}$ and NBT. At equipotent agonist concentrations (see below), the $\alpha 3 \beta 2$ receptor is almost completely blocked by coapplication of $3 \mu \mathrm{M} \mathrm{DH} \beta \mathrm{E}$, whereas the $\alpha 3 \beta 4$ receptor is blocked only slightly. In addition, the $\alpha 3 \beta 2$ combination is completely blocked by $100 \mathrm{~nm}$ NBT, whereas the $\alpha 3 \beta 4$ is insensitive to this concentration of NBT. Because these competitive antagonists distinguish between the receptors based on the identity of the $\beta$ subunits, they are useful probes to identify the structural basis for the contribution of the $\beta$ subunit to competitive antagonist sensitivity.

Amino acid residues involved in determining competitive an- 
Table 1. DH $\beta E$ antagonism can be overcome by increasing the acetylcholine concentration

\begin{tabular}{lccl} 
Receptor & {$[\mathrm{DH} \beta \mathrm{E}](\mu \mathrm{M})$} & {$[\mathrm{ACh}](\mu \mathrm{M})$} & Percent of conirol \\
\hline$\alpha 3 \beta 2$ & 1 & 10 & $21.5 \pm 5.0$ \\
$\alpha 3 \beta 2$ & 1 & 1000 & $96.1 \pm 1.1$ \\
$\alpha 3 \beta 4$ & 30 & 100 & $40.4 \pm 9.9$ \\
$\alpha 3 \beta 4$ & 30 & 10,000 & $95.9 \pm 1.9$ \\
$\alpha 3 \beta 2$, T59K & 10 & 30 & $17.2 \pm 5.8$ \\
$\alpha 3 \beta 2$, T59K & 10 & 3000 & $85.5 \pm 1.8$
\end{tabular}

ACh-induced current in the presence of DHBE is presented as a percentage of the control response to $\mathrm{ACh}$ alone (mean $\pm \mathrm{SD}$ of 3-6 oocytes).

tagonist sensitivity are of particular interest because the competitive antagonist-binding sites of receptors are thought to overlap, at least partially, with the agonist-binding sites. DH $\beta E$ has been shown to act competitively with ACh in ligand-binding experiments on rat brain homogenates (Williams and Robinson, 1984), and essential atomic groups of $\mathrm{DH} \beta \mathrm{E}$ can superimpose with those of the agonist nicotine, suggesting that the two compounds can share a similar conformation (Sheridan et al., 1986). In addition, $\mathrm{DH} \beta \mathrm{E}$ has been shown to be a purely competitive antagonist of the $\alpha 7$ neuronal nAChR exogenously expressed in Xenopus oocytes (Bertrand et al., 1992). We find that $\mathrm{DH} \beta \mathrm{E}$ antagonism of both $\alpha 3 \beta 2$ and $\alpha 3 \beta 4$ can be overcome by increasing the $\mathrm{ACh}$ concentration, a result indicative of compctitive antagonism (Table 1). NBT has also been shown to antagonize $n A C h R s$ in a competitive manner (Halvorsen and Berg, 1987).

To evaluate accurately the degree of blockade by a competitive antagonist such as $\mathrm{DH} \beta \mathrm{E}$ on $\alpha 3 \beta 2$ and $\alpha 3 \beta 4$, it is necessary that the $\mathrm{ACh}$ concentrations used be equipotent (i.e., at the same point on the dose-response curve) (Craig et al., 1993). For this reason, full dose-response curves for each subunit combination were constructed (Fig. $2 A$ ). The $\mathrm{EC}_{50}$ values for $\alpha 3 \beta 2$ and $\alpha 3 \beta 4$ were $70.8 \pm 19.6$ and $209.7 \pm 40.7 \mu \mathrm{M}$, respectively (Table 2 ). The $\mathrm{EC}_{20}$ was chosen as an $\mathrm{ACh}$ test dose, because this is high enough to reliably yield useful current responses, but low enough to avoid extensive desensitization. In contrast to $\mathrm{DH} \beta \mathrm{E}$, incubation with NBT results in pseudoirreversible blockade; NBT slowly dissociates over a period of several hours. Because the postincubation ACh application only lasts for $10 \mathrm{sec}$, the ACh and NBT are not in direct competition. Detcrmination of the percent blockade by NBT, therefore, is unrelated to the level of receptor activation by $\mathrm{ACh}$.

At the $\mathrm{EC}_{20}(10 \mu \mathrm{M}$ for $\alpha 3 \beta 2,100 \mu \mathrm{M}$ for $\alpha 3 \beta 4)$ for each receptor, responses were measured in the presence of increasing $\mathrm{DH} \beta \mathrm{E}$ concentrations (Fig. $2 B$ ). The $\mathrm{IC}_{50}$ values for $\alpha 3 \beta 2$ and $\alpha 3 \beta 4$ were $0.41 \pm 0.17$ and $23.1 \pm 10.2 \mu \mathrm{M}$, respectively. These inhibition curves were used to select $3 \mu \mathrm{M} \mathrm{DH} \beta \mathrm{E}$ as a concentration that differentiates between the receptors. At $3 \mu \mathrm{M} \mathrm{DH} \beta \mathrm{E}$, there is relatively little blockade of the $\alpha 3 \beta 4$ receptor $(86.9 \pm$ $5.1 \%$ of control), whereas most of the $\alpha 3 \beta 2$ response is eliminated $(10.0 \pm 4.6 \%$ of control). An NBT concentration of $100 \mathrm{~nm}$ was chosen to differentiate between the receptors, because this concentration blocks $\alpha 3 \beta 2$ almost completely (3.4 $\pm 1.6 \%$ of control) and has little effect of $\alpha 3 \beta 4$ (96.3 $\pm 8.4 \%$ of control).

\section{Sequence segment 54-63 of $\beta$ subunits contains a major determinant of DH $\beta E$ and NBT sensitivity}

We constructed a series of chimeric $\beta$ subunits to determine which sequence segments are responsible for differences in competitive antagonist sensitivity. Sections of one $\beta$ subunit were substituted
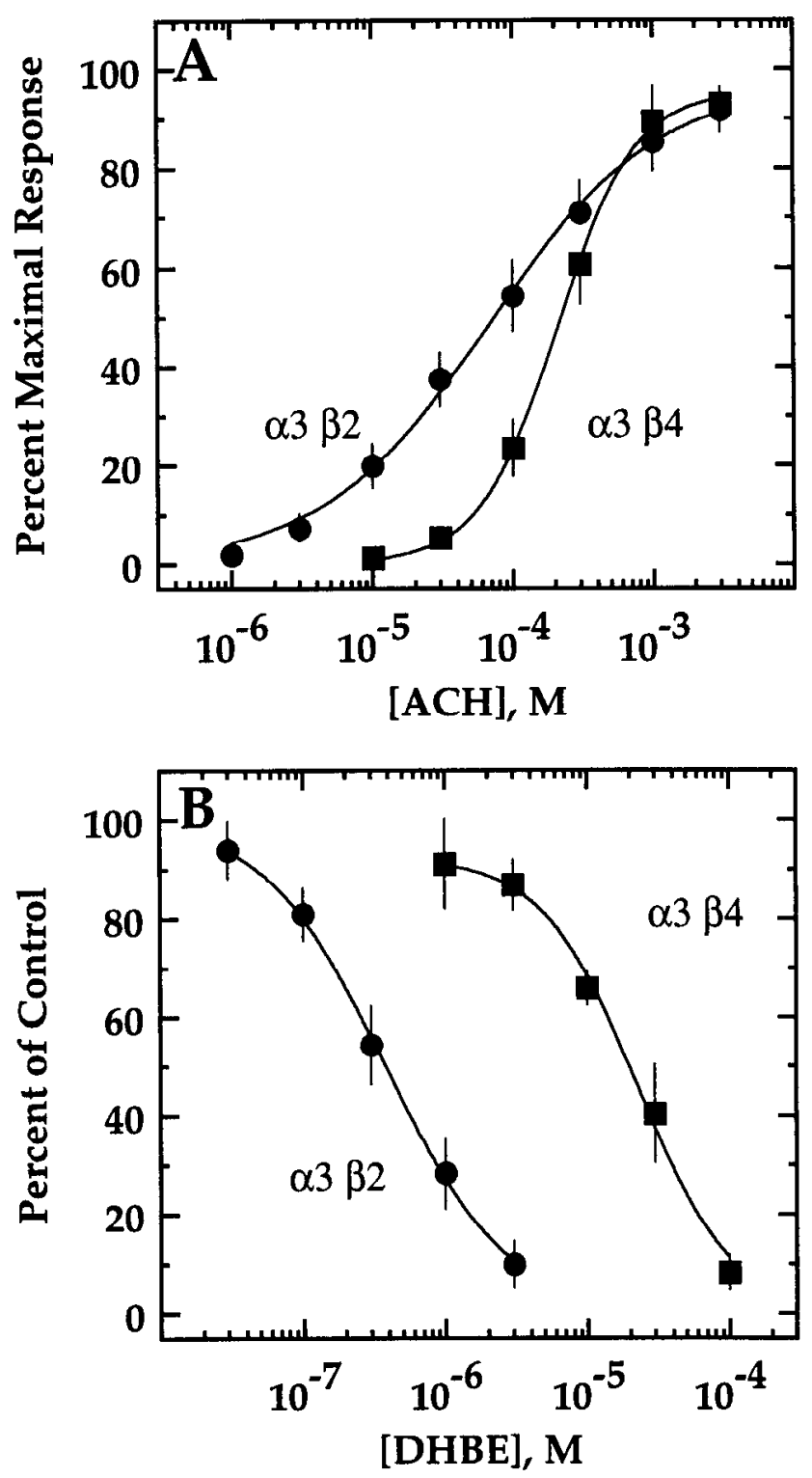

Figure 2. A, Acetylcholine dose-response curves for $\alpha 3 \beta 2$ (circles) and $\alpha 3 \beta 4$ (squares). Symbols are the mean normalized responses + SEM of three separate sets of oocytes, each set consisting of three to four scparate oocytes. The lines are fits to a Hill equation (see Materials and Methods). $\mathrm{EC}_{50}$ and $n$ valucs are $70.8 \pm 19.6 \mu \mathrm{M}$ and $0.74 \pm 0.11$ for $\alpha 3 \beta 2$, respectively, and $209.7 \pm 40.7 \mu \mathrm{M}$ and $1.56 \pm 0.02$ for $\alpha 3 \beta 4$, respectively. $B, \mathrm{DH} \beta E$ inhibition curves for $\alpha 3 \beta 2$ (circles) and $\alpha 3 \beta 4$ (squares). Increasing $\mathrm{DH} \beta \mathrm{E}$ concentrations were coapplied with an $\mathrm{EC}_{20} \mathrm{ACh}$ concentration of $100 \mu \mathrm{M}$ for $\alpha 3 \beta 4$ and $10 \mu \mathrm{M}$ for $\alpha 3 \beta 2$. The response in the presence of $\mathrm{DH} \beta E$ is reported as a percent of the response to ACh alone (mean \pm SD of 3 oocytes). The lincs are fits to a Hill cquation (sec Materials and Methods). $\mathrm{IC}_{50}$ values are $0.41 \pm 0.17 \mu \mathrm{M}$ for $\alpha 3 \beta 2$ and 23.1 $\pm 10.2 \mu \mathrm{M}$ for $\alpha 3 \beta 4$. Some error bars are obscured by symbols.

with homologous sections from the other $\beta$ subunit. In Figure 3 , $A$ and $B$, the chimeras contain an $\mathrm{N}$-terminal section of $\beta 4$ connected to a C-terminal section of $\beta 2$. In Figure 3, $C$ and $D$, the chimeras contain an N-terminal section of $\beta 2$ connected to a C-terminal section of $\beta 4$. Each of these chimeras was then expressed in Xenopus oocytes, in combination with $\alpha 3$, and full dose-response curves were obtained to determine the $\mathrm{EC}_{20}$ for $\mathrm{ACh}$. The degree of blockade of an $\mathrm{EC}_{20} \mathrm{ACh}$ response by $3 \mu \mathrm{M}$ 
Table 2. $\mathrm{EC}_{50}$, Hill coefficient, and $\mathrm{IC}_{50}$ values for receptors formed by wild-type, chimeric, and mutant $\beta$ subunits

\begin{tabular}{lclc} 
Subunit & $\mathrm{EC}_{50}(\mu \mathrm{M})$ & $n$ & $\mathrm{IC}_{50}(\mu \mathrm{M})$ \\
\hline$\beta 2$ & $70.8 \pm 19.6$ & $0.74 \pm 0.11$ & $0.41 \pm 0.17$ \\
$\beta 4$ & $209.7 \pm 40.7$ & $1.56 \pm 0.02$ & $23.1 \pm 10.2$ \\
$\beta 4-54-\beta 2$ & $314.3 \pm 108.8$ & $0.90 \pm 0.20$ & - \\
$\beta 4-103-\beta 2$ & $433.3 \pm 139.3$ & $1.04 \pm 0.16$ & - \\
$\beta 4-133-\beta 2$ & $199.1 \pm 72.4$ & $1.66 \pm 0.45$ & - \\
$\beta 4-204-\beta 2$ & $518.6 \pm 155.7$ & $2.23 \pm 0.30$ & - \\
$\beta 2-54-\beta 4$ & $47.8 \pm 45.3$ & $0.84 \pm 0.26$ & - \\
$\beta 2-63-\beta 4$ & $72.7 \pm 17.1$ & $0.89 \pm 0.02$ & - \\
$\beta 2-74-\beta 4$ & $124.3 \pm 96.8$ & $0.87 \pm 0.22$ & - \\
$\beta 2-80-\beta 4$ & $40.0 \pm 30.5$ & $0.85 \pm 0.12$ & - \\
$\beta 2, \mathrm{~N} 55 \mathrm{~S}$ & $86.3 \pm 47.5$ & $0.57 \pm 0.05$ & - \\
$\beta 2, \mathrm{~V} 56 \mathrm{I}$ & $67.9 \pm 47.3$ & $0.76 \pm 0.10$ & - \\
$\beta 2, \mathrm{~T} 59 \mathrm{~K}$ & $158.5 \pm 114.1$ & $0.92 \pm 0.03$ & $3.8 \pm 0.9$ \\
$\beta 2, \mathrm{E} 63 \mathrm{~T}$ & $94.8 \pm 26.1$ & $0.76 \pm 0.11$ & - \\
$\beta 2, \mathrm{~T} 59 \mathrm{D}$ & $76.2 \pm 45.5$ & $0.78 \pm 0.07$ & $0.30 \pm 0.07$ \\
\hline A & &
\end{tabular}

All subunits were functionally expressed in combination with $\alpha 3 . \mathrm{EC}_{50}$ and $n$ values, determined by fitting to a Hill equation (see Materials and Methods), are the mean $\pm \mathrm{SD}$ of results from three to four separate oocytes, with the exception of $\beta 2$ and $\beta 4$, which are the mean \pm SEM of results from three separate sets of oocytes, cach consisting of three to four separate oocytes. $\mathrm{IC}_{50}$ values, determined by fitting to a Hill equation (see Materials and Methods), dre the niedn \pm SD of results from three separate oocytes.

$\mathrm{DH} \beta \mathrm{E}$ was then determined (Fig. $3 A, C$ ). The degree of blockade by $100 \mathrm{~nm}$ NBT was also determined (Fig. $3 B, D$ ).

Substitution of the first $54 \mathrm{~N}$-terminal residues of $\beta 2$ with the corresponding section of $\beta 4$ ( $\beta 4-54-\beta 2)$ resulted in a subunit that formed receptors that were slightly, but significantly, less sensitive to $3 \mu \mathrm{M} \mathrm{DH} \beta E$ and $100 \mathrm{nM}$ NBT than were receptors formed by wild-type $\beta 2$. This intermediate sensitivity between that of wildtype $\beta 2$ - and $\beta 4$-containing receptors suggests that a minor determinant of $\mathrm{DH} \beta \mathrm{E}$ and NBT sensitivity is located within the first 54 $\mathrm{N}$-terminal amino acids of the $\beta$ subunit. A chimeric subunit in which the first $103 \mathrm{~N}$-terminal residues of $\beta 2$ were replaced with $\beta 4$ sequence ( $\beta 4-103-\beta 2$ ) formed receptors as insensitive to $3 \mu \mathrm{M}$ $\mathrm{DH} \beta \mathrm{E}$ and $100 \mathrm{nM}$ NBT as were receptors formed by wild-type $\beta 4$. This suggests that the section of the $\beta$ subunit responsible for $\mathrm{DH} \beta \mathrm{E}$ and NBT sensitivity is located within the first 103 N-terminal amino acids, with the segment 54-103 containing the major determinant. Chimeric subunits in which the first 133 or 204 N-terminal residues of $\beta 2$ were replaced with $\beta 4$ sequence ( $\beta 4$ $133-\beta 2, \beta 4-204-\beta 2$ ) also formed receptors with DH $\beta E$ and NBT sensitivities comparable to that of wild-type $\beta 4$-containing receptors.

Chimeric subunits were also constructed containing an $\mathrm{N}$-terminal section of $\beta 2$ connected to a $\mathrm{C}$-terminal section of $\beta 4$ (Fig. $3 C, D$ ). Substituting the first $54 \mathrm{~N}$-terminal residues of $\beta 2$ into $\beta 4(\beta 2-54-\beta 4)$ failed to increase the DH $\beta E$ or NBT sensitivity of receptors formed by this chimera beyond that of receptors formed by wild-type $\beta 4$. This result is consistent with the minor nature of the determinant between residues 1 and 54 (Fig. $3 A, B$ ). Substituting the first $63 \mathrm{~N}$-terminal residues of $\beta 2$ into $\beta 4$ ( $\beta 2-63$ $\beta 4$ ) resulted in a chimera that formed receptors as sensitive to blockade by $3 \mu \mathrm{M}$ DH $\beta E$ as receptors formed by $\beta 2$. Substitution of the first 74 or $80 \mathrm{~N}$-terminal residues of $\beta 2$ into $\beta 4$ also resulted in blockade by $3 \mu \mathrm{M} \mathrm{DH} \beta \mathrm{E}$ that was not significantly different than blockade of $\alpha 3 \beta 2$. Receptors formed by $\beta 2-63-\beta 4$ and $\beta 2-$ 74- $\beta 4$ were slightly, but significantly, less sensitive to blockade by $100 \mathrm{nM}$ NBT than were receptors formed by $\beta 2$, whereas the $\beta 2-80-\beta 4$ chimera formed receptors with a sensitivity to $100 \mathrm{~nm}$ NBT indistinguishable from that of receptors formed by $\beta 2$.

Taken together, the $\mathrm{DH} \beta \mathrm{E}$ and NBT sensitivities of receptors formed by these chimeras (Fig. $3 A-D$ ) indicate that the major determinant for sensitivity to both competitive antagonists is within the amino acid segment from 54 to 63 . This can be seen most clearly by considering the chimeras $\beta 4-54-\beta 2$ and $\beta 2-63-\beta 4$. Both $\beta 4-54-\beta 2$, which contains $\beta 2$ sequence from residue 54 to the $\mathrm{C}$ terminus, and $\beta 2-63-\beta 4$, which contains $\beta 2$ sequence from the $\mathrm{N}$ terminus to residue 63 , form receptors nearly as sensitive to $\mathrm{DH} \beta \mathrm{E}$ and NBT blockade as receptors formed by wild-type $\beta 2$. The only $\beta 2$ sequence common to these two chimeras is segment 54-63. In addition to this major determinant, a minor determinant of sensitivity to both antagonists is between 1 and 54, whereas a minor determinant of NBT scnsitivity only may be within segment $74-80$.

\section{Threonine 59 of $\beta 2$ is critical to both $\mathrm{DH} \beta \mathrm{E}$ and NBT sensitivity}

We examined sequence segment $54-63$ in more detail by changing individual amino acid residues. The $\beta 2$ sequence differs from $\beta 4$ at only four residues within this region (Fig. $4 A$ ). We changed each of these residues individually from what occurs in $\beta 2$ to what occurs in $\beta 4$ and then determined the $\mathrm{DH} \beta \mathrm{E}$ and NBT sensitivity of receptors formed by these mutants (Fig. 4B,C). Changing threonine 59 of $\beta 2$ to lysine ( $559 \mathrm{~K}$ ) resulted in a significant loss in sensitivity to $\mathrm{DH} \beta \mathrm{E}$ and NBT when compared to wild-type $\beta 2$ containing receptors. Mutation V56I had a small, but significant, effect on both DH $\beta$ E and NB'I' sensitivity. Mutation N55S had a small, but significant, effect on DH $\beta E$ sensitivity, but no effect on NBT sensitivity, whereas mutation E63T had no effect on sensitivity to either antagonist.

In Figure 5 we examined in more detail the degree to which mutation T59K affected DH $\beta$ E and NBT sensitivity. The DH $\beta E$ inhibition curve for receptors formed by $\beta 2, \mathrm{~T} 59 \mathrm{~K}$ is shifted to the right of the wild-type $\beta 2$ curve approximately ninefold, accounting for about half of the difference between $\beta 2$ - and $\beta 4$-containing receptors (Fig. $5 A$ ). Block of $\beta 2, \mathrm{~T} 59 \mathrm{~K}$-containing receptors by $\mathrm{DH} \beta \mathrm{E}$ remains competitive because an increased $\mathrm{ACh}$ concentration is able to overcome blockade (Table 1). Residue 59, together with residues 55 and 56 , is responsible for most of the difference in $\mathrm{DH} \beta E$ sensitivity between $\beta 2$ and $\beta 4$. This can be seen most clearly by considering that blockade of $\beta 2$ - and $\beta 4$ containing receptors by $3 \mu \mathrm{M} \mathrm{DH} \beta \mathrm{E}$ differs by $\sim 77$ percentage points. Block of mutants $\beta 2, \mathrm{~N} 55 \mathrm{~S}, \beta 2, \mathrm{~V} 56 \mathrm{l}$, and $\beta 2, \mathrm{~T} 59 \mathrm{~K}$ by $\mathrm{DH} \beta \mathrm{E}$ differs from block of $\beta 2$ by 10,9 , and 41 percentage points, respectively, accounting for 60 percentage points. The remaining difference between block of $\beta 2$ - and $\beta 4$-containing receptors (17 percentage points) is completely accounted for by segment $1-54$, because block of $\beta 4-54-\beta 2$ receptors differs from that of $\beta 2$ receptors by 19 percentage points. Threonine 59 also accounts for a substantial portion of the NBT sensitivity difference between $\beta 2$ and $\beta 4$-containing receptors (Fig. $5 B$ ). Receptors formed by $\beta 2$, T59K were $\sim 71$-fold less sensitive to NBT than $\beta 2$-containing receptors. Although we know that $\alpha 3 \beta 4$ is at least 100 -fold less sensitive to NBT than $\alpha 3 \beta 2$ (Fig. $5 B$ ), we are unable to determine exactly how much less sensitive $\alpha 3 \beta 4$ is attributable to a lack of a sufficient quantity of NBT. The remaining difference in NBT sensitivity between $\beta 2$ - and $\beta 4$-containing receptors can be accounted for by the slight contribution from V56 and the minor determinants within regions $1-54$ and 74-80.

The loss of $\mathrm{DH} \beta \mathrm{E}$ and NBT sensitivity caused by the mutation 


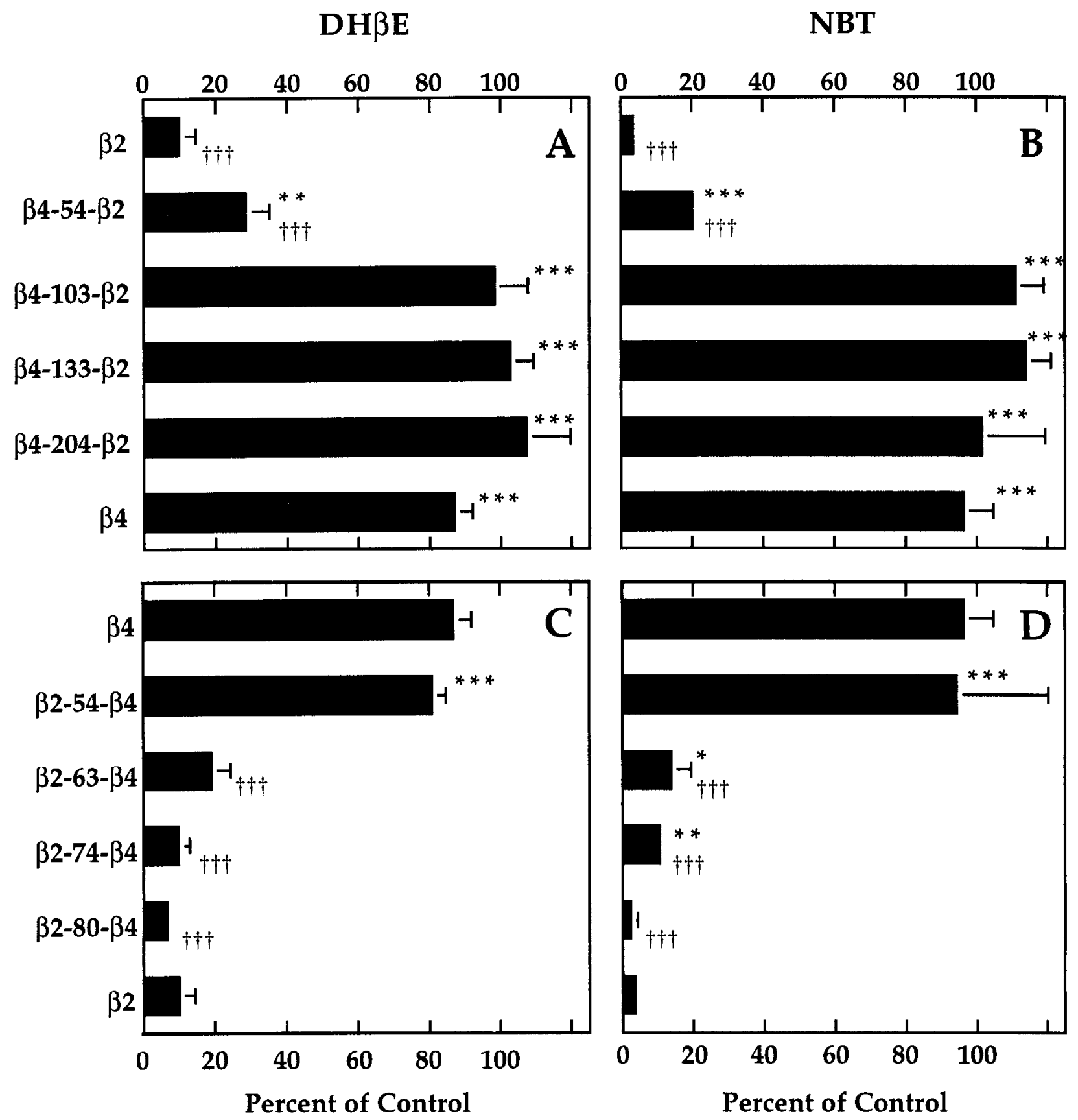

Figure 3. DH $\beta \mathrm{E}$ and NBT sensitivity of receptors formed by chimeric $\beta$ subunits. $A, \mathrm{DH} \beta \mathrm{E}$ sensitivity of receptors formed by each of a series of chimeric subunits in which increasingly larger portions of the N-terminal end of $\beta 2$ were replaced by the corresponding portion of $\beta 4$. Current in response to an $\mathrm{EC}_{20}$ concentration of $\mathrm{ACh}$ in the presence of $3 \mu \mathrm{M} \mathrm{DH} \beta \mathrm{E}$ is presented as a percent of the response to ACh alone (mean $\pm \mathrm{SD}$ of 3-4 separate oocytes). $B$, NBT sensitivity of receptors formed by the chimeras in $A$. Current in response to an ACh concentration at or below the $\mathrm{EC}_{50}$ after 30 min incubation with $100 \mathrm{nM}$ NBT is presented as a percentage of the response to ACh alone (mean \pm SD of 3-4 separate oocytes, cxcept for $\beta 4$, which is mean \pm SEM of 3 separate sets of oocytes, each set consisting of 3-4 separate oocytes). $C$, DH $\beta E$ sensitivity of receptors formed by each of a series of chimeric subunits in which increasingly larger portions of $\beta 4$ were replaced by the corresponding portion of $\beta 2$. Current in response to an $\mathrm{EC}_{20}$ concentration of $\mathrm{ACh}$ in the presence of $3 \mu \mathrm{M} \mathrm{DH} \beta E$ is presented as a percent of the response to ACh alone (mean \pm SD of 3-4 separate oocytes). $D$, NBT sensitivity of receptors formed by the chimeras in $C$. Current in response to an $\mathrm{ACh}$ concentration at or below the $\mathrm{EC}_{50}$ after 30 min incubation with $100 \mathrm{nM}$ NBT is presented as a percentage of the response to ACh alone (mean \pm SD of 3-4 separate oocytes, except for $\beta 2-54-\beta 4$, which is mean \pm SEM of 3 separate sets of oocytes, each set consisting of 3-4 separate oocytes). Significant differences from $\beta 2$ are denoted by asterisks $\left({ }^{*} p<0.05 ;{ }^{* *} p<0.01 ;{ }^{* *} p<0.001\right)$. Significant differences from $\beta 4$ are denoted by daggers $\left({ }^{\dagger} p<0.05 ;{ }^{\dagger \dagger} p<0.001\right.$ ). Some error bars are too small to appear.

T59K could be attributable to the change from the polar side chain of threonine to the positively charged side chain of lysine, or it could be attributable to the change in side chain volume. The identification of arginine 34 of NBT as a critical residue for neuronal nAChR blockade (Dewan et al., 1994; Fiordalisi et al.,
1994) suggests that it is the introduction of the positively charged lysine that interferes NBT sensitivity. To explore this idea, we introduced a negative charge by changing this residue from threonine to aspartate (T59D). The DH $\beta \mathrm{E}$ and NBT sensitivity of receptors formed by $\beta 2$,T59D is shown in Figure $5, A$ and $B$. The 

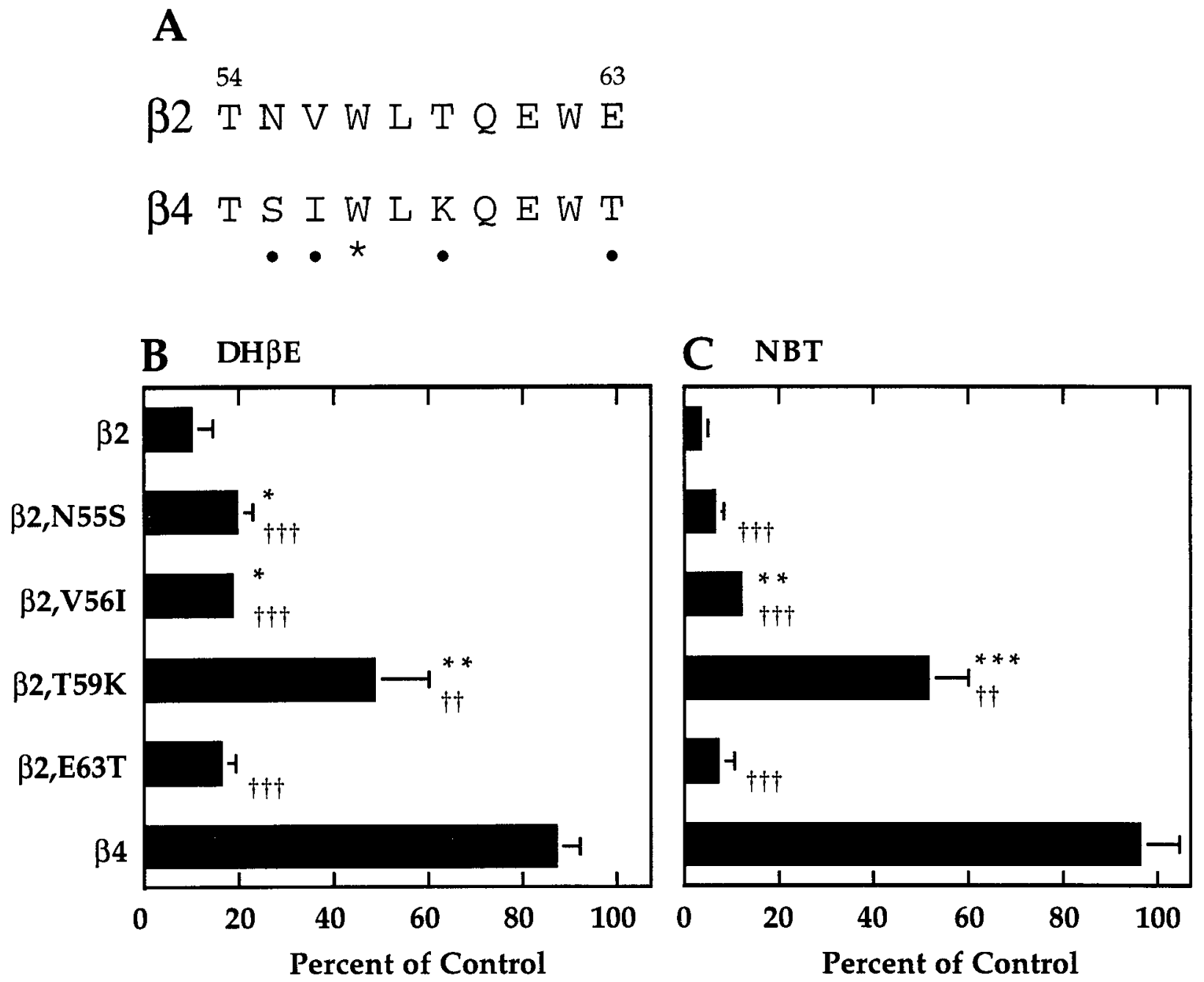

Figure 4. Threonine 59 of $\beta 2$ is critical to both $\mathrm{DH} \beta \mathrm{E}$ and NBT sensitivity. A, Alignment of $\beta 2$ and $\beta 4$ sequences within segment $54-63$. Residues that differ are denoted by solid circles. Tryptophan 57 is starred. B, DH $\beta \mathrm{E}$ sensitivity of receptors formed by each of a series of mutant $\beta 2$ subunits. Current in response to an $\mathrm{EC}_{20}$ concentration of $\mathrm{ACh}$ in the presence of $3 \mu \mathrm{M} \mathrm{DH} \beta \mathrm{E}$ is presented as a percent of the response to $\mathrm{ACh}$ alone (mean $\pm \mathrm{SD}$ of 3 separate oocytes). $C$, NBT sensitivity of receptors formed by the $\beta 2$ mutants in $B$. Current in response to an $A C h$ concentration at or below the EC $C_{50}$ after $30 \mathrm{~min}$ incubation with $100 \mathrm{nM}$ NBT is presented as a percentage of the response to ACh alone (mean \pm SD of 3 separate oocytes, except for $\beta 4$, which is mean \pm SEM of three separate sets of oocytes, each set consisting of 3-4 separate oocytes). Significant differences from $\beta 2$ are denoted by asterisks $\left({ }^{*} p<0.05 ;{ }^{* *} p<0.01 ;{ }^{* *} p<0.001\right)$. Significant differences from $\beta 4$ are denoted by daggers $\left({ }^{\dagger+} p<0.01\right.$; $\left.{ }^{\dagger \dagger} p<0.001\right)$. Some error bars are too small to appear.

T59D mutation resulted in an increase in NBT sensitivity of $\sim 2.5$ fold. The T59D mutation had no effect on DH $\beta$ E sensitivity.

\section{DISCUSSION}

The neuronal nAChRs $\alpha 3 \beta 2$ and $\alpha 3 \beta 4$ differ in their sensitivity to the antagonists $\mathrm{DH} \beta \mathrm{E}$ and NBT. Pharmacological analysis of a series of chimeric $\beta$ subunits has allowed us to identify areas of the $\beta$ subunits that determine sensitivity to these competitive antagonists. The major determinant of both DH $\beta \mathrm{E}$ and NBT sensitivity lies in sequence segment 54-63, with a minor determinant of sensitivity to both antagonists in region 1-54 and a minor determinant of NBT sensitivity in region 74-80. Within sequence segment 54-63, we identified threonine 59 of $\beta 2$ as the critical residue. Changing this residue to lysine, as in $\beta 4$, results in a 9 -fold loss in $\mathrm{DH} \beta \mathrm{E}$ sensitivity and a 71 -fold loss in NBT sensitivity. Changing threonine 59 of $\beta 2$ to aspartate, thus introducing a negative charge, caused a 2.5 -fold increase in NBT sensitivity.

It has become clear recently that non- $\alpha$ subunits are involved in determining both the physical structure and pharmacological properties of the ligand-binding sites of nAChRs (Blount and Merlie, 1989; Duvoisin et al., 1989; Pederson and Cohen, 1990; Czajkowski and Karlin, 1991; Luetje and Patrick, 1991; Middleton and Colıen, 1991). Affinity labeling and mutagenesis studies of Torpedo electric organ and mammalian muscle $\mathrm{nAChRs}$ have identified amino acid residues of the $\gamma$ and $\delta$ subunits that are associated with ligand binding (Cohen et al., 1992; Czajkowski et al., 1993; Sine, 1993; Fu and Sine, 1994). In covalent labeling experiments involving the competitive antagonist $d$-tubocurarine, Cohen et al. (1992) demonstrated incorporation of label onto a tryptophan residue of the $\gamma$ and $\delta$ subunits (residue 55 and 57 , respectively). This residue is conserved in the rat neuronal $\beta 2$ and $\beta 4$ subunits (position 57, Fig. 4A), and thus appears to be a common feature of the ligand-binding sites of nAChRs. Interestingly, the homologous residue of neuronal $\alpha 7$ (tryptophan 54) is involved in determining sensitivity to both agonists and antago- 

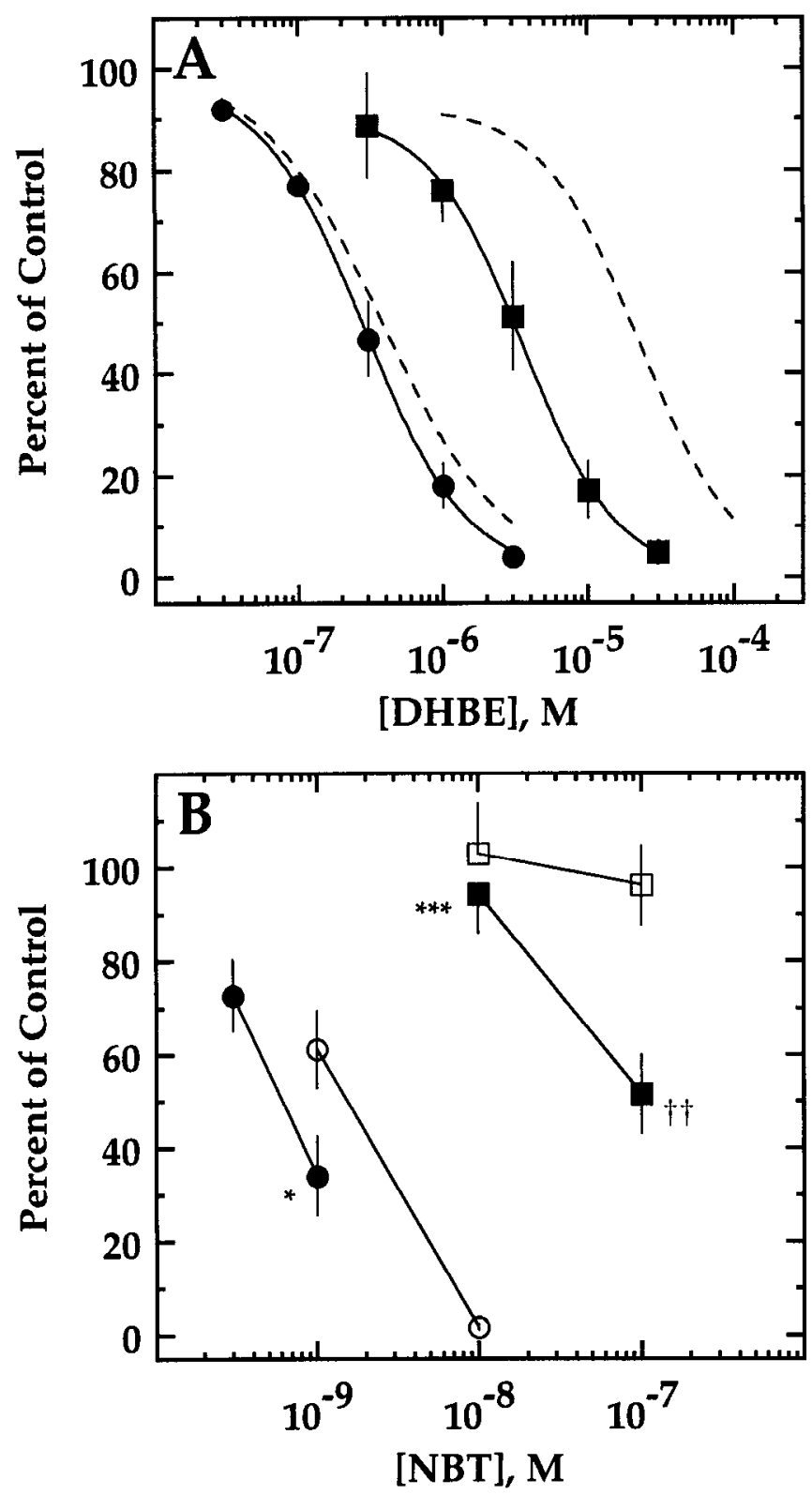

Figure 5. Effect of mutations of threonine 59 on DH $\beta E$ and NBT sensitivity. $A, \mathrm{DH} \beta \mathrm{E}$ sensitivity of $\alpha 3 \beta 2, \mathrm{~T} 59 \mathrm{~K}$ (filled squares) and $\alpha 3 \beta 2$,T59D (filled circles). Current in response to an $\mathrm{EC}_{20}$ concentration of $\mathrm{ACh}$ in the presence of various concentrations of $\mathrm{DH} \beta \mathrm{E}$ is presented as a percent of the response to $\mathrm{ACh}$ alone (mean \pm SD of 3-6 oocytes). The lines are fits to a Hill equation (see Matcrials and Mcthods). $\mathrm{IC}_{50}$ values are $3.8 \pm 0.9 \mu \mathrm{M}$ for $\alpha 3 \beta 2, \mathrm{~T} 59 \mathrm{~K}$ and $0.30 \pm 0.07 \mu \mathrm{M}$ for $\alpha 3 \beta 2$,T59D. Inhibition curves for $\alpha 3 \beta 2$ and $\alpha 3 \beta 4$ from Figure $2 B$ are shown as dashed lines for reference. $B$, NBT sensitivity of $\alpha 3 \beta 2, \mathrm{~T} 59 \mathrm{~K}$ (filled squares), $\alpha 3 \beta 2, \mathrm{T59D}$ (filled circles), $\alpha 3 \beta 2$ (open circles), and $\alpha 3 \beta 4$ (open squares). Current in response to an ACh concentration at or below the $\mathrm{EC}_{50}$ after $30 \mathrm{~min}$ incubation with various concentrations of NBT is presented as a percentage of the response to $\mathrm{ACh}$ alone (mean $\pm \mathrm{SD}$ of 3 separate oocytes). Significant differences from $\beta 2$ are denoted by asterisks $\left({ }^{*} p<0.02 ;{ }^{* * *} p<0.001\right)$. Significant differences from $\beta 4$ are denoted by daggers $\left({ }^{+\dagger} p<0.01\right)$. Some error bars are obscured by symbols.

nists, leading to the proposal that $\alpha 7$ contributes both an " $\alpha$ component" and a "non- $\alpha$ component" when forming homooligomeric receptors (Corringer et al., 1995).

The conservation of this tryptophan among muscle and neuronal nAChRs means that this residue cannot be responsible for pharmacological differences between $\mathrm{nAChR}$ subtypes. It is the amino acid residues that differ among subunits that must be responsible for this diversity. We have identified such a residue, separated by only one residue from the conserved tryptophan, as the major determinant of differences in competitive antagonist sensitivity between $\beta 2$ - and $\beta 4$-containing receptors. Changing this residue in $\beta 2$ from threonine to what occurs in $\beta 4$ (lysine) results in a substantial loss of both $D H \beta E$ and NBT sensitivity. The change from threonine to lysine is a change in both the character (polar to negatively charged) and the size (55.7-101.5 $\AA^{3}$ ) of the side chain. Either or both of these properties might be responsible for the effect of changing this residue. Considering that arginine 34 of NBT has been identified as a critical residue involved in neuronal nAChR blockade (Dewan et al., 1994), we hypothesized that insertion of lysine at position 59 in $\beta 2$ might be decreasing NBT sensitivity by electrostatic repulsion. If this were true, then introduction of a negative charge at this position might be expected to increase NBT sensitivity. Changing threonine 59 to aspartate does result, in fact, in an increase in NBT sensitivity (Fig. $5 B$ ).

Construction and functional analysis of chimeric receptor subunits allows identification of structural differences that confer unique pharmacological properties. This methodology has been used to map determinants of both agonist and antagonist sensitivity on neuronal $\mathrm{nAChR} \beta$ subunits. Chimeric subunits have been used to identify the general region on $\beta$ subunits that contributes to NBT sensitivity. Papke et al. (1993) showed that substitution of the first 119 amino acids of the $\beta 4$ subunit with the corresponding section of $\beta 2$ can confer NBT sensitivity onto the $\beta 4$ subunit. The identity of the $\beta$ subunit also influences the NBT sensitivity of the receptors $\alpha 4 \beta 2$ and $\alpha 4 \beta 4$. Wheeler et al. (1993) showed that a chimeric subunit composed of the $\mathrm{N}$-terminal 80 residues of $\beta 2$ followed by $\beta 4$ sequence, formed receptors with $\alpha 4$ that were sensitive to NBT blockade. A series of $\beta$ subunit chimeras, expressed in combination with the $\alpha 3$ subunit, has been used to identify the sequence segment $104-120$ of $\beta 2$ as important in determining sensitivity to the agonist cytisine (Figl et al., 1992; Cohen et al., 1995). Consistent with these reports, we find that receptors formed by $\alpha 3$ and the chimera $\beta 4-103-\beta 2$ have a cytisine sensitivity similar to that of receptors formed by wild-type $\alpha 3 \beta 2$ (data not shown). Cohen et al. (1995) also show that region 104-120 is responsible for part of the difference in $\mathrm{EC}_{50}$ for $\mathrm{ACh}$, as well as for part of the difference in Hill slope, between $\alpha 3 \beta 2$ and $\alpha 3 \beta 4$.

Differential sensitivity to agonists may result from differences in affinity or efficacy, making it difficult to infer conclusions about the functional role of the sequence segment being mapped. Competitive antagonists are ideal probes, because they compete with agonist for a common binding site but do not activate the receptors; they have no efficacy. Because our determination of the $\mathrm{DH} \beta \mathrm{E}$ sensitivity of each receptor is dependent on use of equipotent concentrations of $\mathrm{ACh}$, it is important that differences in $\mathrm{DH} \beta \mathrm{E}$ sensitivity not be an artifact of differences in ACh doseresponse curve characteristics. The $\alpha 3 \beta 2$ and $\alpha 3 \beta 4 \mathrm{ACh}$ doseresponse curves clearly differ in both $\mathrm{EC}_{50}$ and apparent Hill coefficient (Table 2). However, these differences can be taken into consideration when $\mathrm{DH} \beta \mathrm{E}$ dissociation constants $\left(K_{\mathrm{i}}\right)$ for each receptor are calculated (Leff and Dougall, 1993). The resulting $\mathrm{DH} \beta \mathrm{E} K_{\mathrm{i}}$ values of 0.21 and $32.4 \mu \mathrm{M}$ (for $\alpha 3 \beta 2$ and $\alpha 3 \beta 4$, respectively) differ by $\sim 154$-fold. Additional arguments against differences in $\mathrm{DH} \beta \mathrm{E}$ sensitivity being artifactual are that $\mathrm{DH} \beta \mathrm{E}$ sensitivity maps differently than the $\mathrm{ACh}^{\mathrm{EC}_{50}}$ and the apparent 
Hill coefficient (compare Fig. 3 and Table 2), and that use of both $\mathrm{DH} \beta \mathrm{E}$ and NBT as probes has identified the same residue as a major determinant of competitive antagonist sensitivity. If $\mathrm{DH} \beta \mathrm{E}$ antagonism is competitive, why do determinants of $\mathrm{DH} \beta \mathrm{E}$ sensitivity and $\mathrm{ACh}_{\mathrm{EC}}$ ) differ? Although competitive antagonists do compete for a common binding site with agonists, their interactions with the binding site would not necessarily be coextensive with those of agonists. In fact, this would not be expected, because competitive antagonists differ from agonists by lacking efficacy.

Although the pseudoirreversibility of NBT blockade makes concerns over ACh dose-response curves irrelevant, NBT is a large peptide toxin and may block receptor activation by adventitiously occluding the ligand-binding site after binding elsewhere on the receptor. Therefore, mapping the areas of the receptor responsible for differential sensitivity to NBT may identify regions of uncertain significance. However, both $\mathrm{DH} \beta \mathrm{E}$ and NBT sensitivity map similarly, identifying threonine 59 as a major determinant and region 1-54 as containing a minor determinant, supporting the view that NBT is a useful probe. The significance of region 74-80, containing an additional minor determinant of NBT sensitivity, is unclear. Another example of determinants of NBT sensitivity overlapping with those of small ligand sensitivity occurs on $\alpha$ subunits. The $\alpha 2$ subunit forms receptors with $\beta 2$ that are insensitive to NBT and are more sensitive to nicotine than to ACh, whereas $\alpha 3 \beta 2$ receptors are blocked by NBT and are much less sensitive to nicotine than to ACh. Region 195-215 contains determinants of both properties. Within this region, the glutamine residue at position 198 of $\alpha 3$ (proline in $\alpha 2$ ) was shown to be an important determinant of both NBT and nicotine sensitivity (Luetje et al., 1993). Similar results regarding the role of glutamine 198 in determining nicotine sensitivity have been obtained recently using chicken neuronal nAChR $\alpha$ subunits (Hussy et al., 1994).

The exact physical role of residues identified in this and previous studies, that confer pharmacological differences among nAChR subtypes, remains unclear. In this study, we provide data consistent with a direct interaction between residue 59 of $\beta 2 / \beta 4$ and NBT. Thus, these residues may be structural features of the binding site and may participate in the binding of ligand. Alternatively, these residues may not actually participate in binding of ligand, but impinge upon those that do, reshaping the site enough to alter ligand sensitivity. More extensive mutagenesis of identified residues will be required to distinguish between these possibilities. Particularly promising is the potential for incorporating unnatural amino acids at these sites (Nowak et al., 1995).

\section{REFERENCES}

Abramson SN, Li Y, Culver P, Taylor P (1989) An analog of lophotoxin reacts covalently with $\mathrm{Tyr}^{1 \% 0}$ in the $\alpha$-subunit of the nicotinic acetylcholine receptor. J Biol Chem 264:12666-12672.

Bertrand D, Bertrand S, Ballivet M (1992) Pharmacological properties of the homomeric $\alpha 7$ receptor. Neurosci Lett 146:87-90.

Blount P, Merlie J (1989) Molecular basis of the two nonequivalent ligand binding sites of the muscle nicotinic acetylcholine receptor. Neuron 3:349-357.

Boulter J, Connolly J, Deneris E, Goldman D, Heinemann S, Patrick J (1987) Functional expression of two neuronal nicotinic acetylcholine receptors from cDNA clones identifies a gene family. Proc Natl Acad Sci USA 84:7763-7767.

Cohen JB, Blanton MP, Chiara DC, Sharp SD, White BH (1992) Structural organization of functional domains of the nicotinic acetylcholine receptor. J Cell Biochem [Suppl] 16E:217.

Cohen BN, Figl A, Quick MW, Labarca C, Davidson N, Lester HA (1995) Regions of $\beta 2$ and $\beta 4$ responsible for differences between the steady state dose-response relationships of the $\alpha 3 \beta 2$ and $\alpha 3 \beta 4$ neuronal nicotinic receptors. J Gen Physiol 105:745-764.

Corringer PJ, Galzi JL, Eisele JL, Bertrand S, Changeux JP, Bertrand D (1995) Identification of a new component of the agonist binding site of the nicotinic alpha 7 homooligomeric receptor. J Biol Chem 270:11749-11752.

Craig DA (1993) The Cheng-Prusoff relationship: somelling lust in the translation. Trends Pharmacol Sci 14:89-91.

Czajkowski C, Karlin A (1991) Agonist binding site of Torpedo electric tissue nicotinic acetylcholine receptor: a negatively charged region of the $\delta$ subunit within $0.9 \mathrm{~nm}$ of the $\alpha$ subunit binding site disulfide. J Biol Chem 266:22603-22612.

Czajkowski C, Kaufmann C, Karlin A (1993) Negatively charged amino acid residues in the nicotinic receptor $\gamma$ subunit that contribute to the binding of acetylcholine. Proc Natl Acad Sci USA 90:6285 6289.

Dennis M, Giraudat J, Kotzyba-Hibert F, Goeldner M, Hirth C, Chang J-Y, Lazure C, Chretien M, Changeux J-P (1988) Amino acids of the Torpedo marmorata acetylcholine receptor $\alpha$ subunit labelled by photoaffinity ligand for acetylcholine binding site. Biochemistry 27:2346-2357.

Dewan JC, Grant GA, Sacchettini JC (1994) Crystal structure of $\kappa$-bungarotoxin at $2.3-\AA$ resolution. Biochemistry $33: 13147-13154$.

Duvoisin RM, Deneris ES, Boulter J, Patrick J, Heinemann S (1989) The functional diversity of the neuronal nicotinic acetylcholine receptors is increased by a novel subunit: $\beta 4$. Ncuron 3:487-496.

Elgoyhen $\Lambda \mathrm{B}$, Johnson DS, Boulter J, Vetter DE, Heinemann $\mathrm{S}$ (1994) $\alpha 9$ : an acetylcholine receptor with novel pharmacological properties expressed in rat cochlear hair cells. Cell 79:705-715.

Figl A, Cohen BN, Quick MW, Davidson N, Lester HA (1992) Regions of $\beta 4-\beta 2$ subunit chimeras that contribute to the agonist selectivity of neuronal nicotinic receptors. FEBS Lett 308:245-248.

Fiordalisi JJ, Al-Rabiee R, Chiappinelli VA, Grant GA (1994) Sitedirected mutagencsis of $\kappa$-bungarotoxin: implications for neuronal receptor specificity. Riochemistry 33:3872-3877.

Fu DX, Sine SM (1994) Competitive antagonists bridge the $\alpha-\gamma$ subunit interface of the acetylcholine receptor through quaternary ammoniumaromatic interactions. J Biol Chem 269:26152-26157.

Galzi J, Revah F, Black D, Goeldner M, Hirth C, Changeux J-P (1990) Identification of a novel amino acid $\alpha$-tyrosine 93 within the cholinergic ligands-binding sites of the acetylcholine receptor by photoaffinity labeling. J Biol Chem 265:10430-10437.

Halvorsen SW, Berg DK (1987) Affinity labeling of neuronal acetylcholine receptor subunits with an $\alpha$-neurotoxin that blocks receptor function. J Neurosci 7:2547-2555.

Higuchi R (1990) Recombinant PCR. In: PCR protocols, a guide to methods and applications (Innis MA, Gelfand GH, Sninsky JJ, White TJ, eds). San Diego: Academic.

Hussy N, Ballivet M, Bertrand D (1994) Agonist and antagonist effects of nicotine on chick neuronal nicotinic receptors are defined by $\alpha$ and $\beta$ subunits. J Neurophys 72:1317-1326.

Kao PN, Dwork AJ, Kaldany R-RJ, Silver MS, Wideman J, Stein S, Karlin A (1984) Identification of the $\alpha$ subunit half-cystine specifically labeled by an affinity reagent for the acetylcholine receptor binding site. J Biol Chem 259:11662-11665.

Leff P, Dougall IG (1993) Further concerns over Cheng-Prusoff analysis. Trends Pharmacol Sei 14:110 112.

Luetje CW, Patrick J (1991) Both $\alpha$ - and $\beta$-subunits contribute to the agonist sensitivity of ncuronal nicotinic acetylcholine receptors. J Neurosci $11: 837-845$.

Luetje CW, Patrick J, Séguéla $\mathbf{P}$ (1990a) Nicotine receptors in the manmalian brain. FASEB J 4:2753-2760.

Luetje CW, Wada K, Rogers S, Abramson SN, Tsuji K, Heinemann S, Patrick J (1990b) Neurotoxins distinguish between different neuronal nicotinic acetylcholine receptor subunit combinations. J Neurochem 55:632-640.

Luetje CW, Piattoni M, Patrick J (1993) Mapping of ligand binding sites of neuronal nicotinic acctylcholine receptors using chimeric $\alpha$ subunits. Mol Pharmacol 44:657-666.

Middleton RE, Cohen JB (1991) Mapping of the acetylcholine binding site of the nicotinic acetylcholine receptor: $\left[{ }^{3} \mathrm{H}\right]$ nicotine as an agonist photoaffinity label. Biochemistry 30:6987-6997.

Nowak MW, Kearney PC, Sampson JR, Saks ME, Labarca CG, Silverman SK, Zhong W, Thorson J, Abelson JN, Davidson N, Schulz PG, Dougherty DA, Lester HA (1995) Nicotinic receptor binding site probed with 
unnatural amino acid incorporation in intact cells. Science 268:439-442.

Papke RL, Boulter J, Patrick J, Heinemann S (1989) Single-channel currents of rat neuronal nicotinic acetylcholine receptors expressed in Xenopus oocytes. Neuron 3:589-596.

Papke RL, Duvoisin RM, Heinemann S (1993) The amino terminal half of the nicotinic $\beta$-subunit extracellular domain regulates the kinetics of inhibition by neuronal bungarotoxin. Proc $R$ Soc Lond [Biol] 252:141-148.

Pedersen SE, Cohen JB (1990) $d$-Tubocurarine binding sites are located at the $\alpha-\gamma$ and $\alpha-\delta$ subunit interfaces of the nicotinic acetylcholine receptor. Proc Natl Acad Sci USA 87:2785-2789.

Rule LW (1992) Diversity in primary structure and function of ncuronal nicotinic acetylcholine receptor channels. Curr Opin Neurobiol $2: 254-262$
Sargent PB (1993) The diversity of neuronal nicotinic acetylcholine receptors. Annu Rev Neurosci 16:403-443.

Sheridan RP, Nilakantan R, Dixon JS, Venkataraghavan R (1986) The ensemble approach to distance geometry: application to the nicotinic pharmacophore. J Med Chem 29:899-906.

Sine SM (1993) Molecular dissection of subunit interfaces in the acetylcholine receptor: identification of residues that determine curare selectivity. Proc Natl Acad Sci USA 90:9436 -9440.

Wheeler SV, Chad JE, Foreman R (1993) Residues 1 to 80 of the $\mathrm{N}$-terminal domain of the $\beta$ subunit confer neuronal bungarotoxin sensitivity and agonist sensitivity on neuronal nicotinic receptors. FEBS Lett 332:139-142.

Williams M, Robinson JL (1984) Binding of the nicotinic cholinergic antagonist dihydro- $\beta$-erythroidine to rat brain tissue. J Neurosi 4:29062911. 